\title{
PERUT SINCAN (Snakes and Ladders Game of Disaster Mitigation) as a Disaster Education Learning Medium
}

\author{
Universitas Sebelas Maret \\ skadutami@gmail.com
}

Siska Dwi Utami, Hapsari’ati Mustari

\section{Article History}

accepted 31/08/2020

approved 22/09/2020

published $28 / 10 / 2020$

\begin{abstract}
The Indonesian people really need insight into disaster mitigation, especially strengthening disaster mitigation which is one form of implementation of the 2030 Sustainable Development Goals (SDGs) goal 13. Disaster mitigation can basically be implanted through education. Disaster mitigation education from an early age, especially in elementary schools, is needed to form a generation of young Indonesians who are resilient to disasters. So that interactive learning media is needed, one of which is a game of snake and ladder modified with disaster mitigation material. This innovation is called PERUT SINCAN (Disaster Mitigation Snake Game) which has 25 posts containing challenges with disaster materials. The formulation of the problem is the concept of implementation, implementation, and implications of the SINCAN STATE. The research method used is descriptive method using qualitative data. Data collection techniques using data analysis techniques from related literature. With this interactive learning media, it is hoped that it can add insight and raise awareness of the importance of disaster mitigation in children.
\end{abstract}

Keywords: Disaster, Education, Traditional Game

\begin{abstract}
Abstrak
Masyarakat Indonesia sangat memerlukan wawasan tentang mitigasi bencana, terlebih lagi penguatan mitigasi bencana yang merupakan salah satu bentuk implementasi dari Sustainable Development Goals (SDGs) tahun 2030 tujuan ke 13. Mitigasi bencana pada dasarnya dapat ditanamkan melalui jalur pendidikan. Pendidikan mitigasi bencana sejak usia dini khususnya di sekolah dasar sangat diperlukan untuk membentuk generasi muda Indonesia yang tangguh akan bencana. Sehingga diperlukan media pembelajaran interaktif, salah satunya yaitu berupa permainan ular tangga yang dimodifikasi dengan adanya materi mitigasi bencana. Inovasi ini dinamakan PERUT SINCAN (Permainan Ular Tangga Mitigasi Bencana) yang mana memiliki 25 pos yang berisi tantangan dengan materi bencana. Rumusan masalahnya yaitu konsep penerapan, implementasi, dan implikasi dari PERUT SINCAN. Metode penelitian yang digunakan adalah metode deskriptif dengan menggunakan data kualitatif. Teknik pengumpulan data menggunakan teknik analisis data dari literatur yang terkait. Dengan adanya media pembelajaran interaktif ini, diharapkan dapat menambah wawasan dan menumbuhkan kesadaran pentingnya mitigasi bencana pada anak-anak.
\end{abstract}

Kata kunci: Bencana, Pendidikan, Permainan Tradisional

Social, Humanities, and Education Studies (SHEs): Conference Series https://jurnal.uns.ac.id/shes 


\section{PENDAHULUAN}

Dilihat dari letak dan kondisi fisik, Indonesia merupakan negara yang memiliki risiko tinggi terhadap terjadinya bencana karena secara geologis terletak pada pertemuan Lempeng Eurasia, Lempeng Indo-Australia, dan Lempeng Pasifik. Semua itu membentuk rangkaian pegunungan Sirkum Mediterania dan Sirkum Pasifik, yang bertemu di Indonesia, tepatnya di Laut Banda, Maluku. Secara geografis, Indonesia merupakan negara kepulauan dengan bentuk topografi yang bervariasi (Desfandi, 2014). Hal ini menandakan bahwa posisi Indonesia berada di daerah yang rawan bencana, baik bencana karena aktivitas geologi seperti gempa bumi, longsor, tsunami, maupun bencana karena perubahan iklim yang tajam seperti banjir, kekeringan, kebakaran hutan dan sebagainya (BPPT, 2018).

BNPB (2020) mencatat 1.549 kejadian bencana alam terjadi hingga akhir Juni 2020 yang didominasi oleh bencana hidrometeorologi seperti banjir, tanah longsor, dan angin putting beliung. Bencana alam tersebut mengakibatkan korban meninggal sebanyak 198 jiwa, hilang 8 jiwa, luka-luka 273 jiwa, dan mengunsi 2,3 juta jiwa. Selain korban jiwa, kerugian juga berupa rumah rusak sebanyak 21.496 unit, fasilitas kesehatan 67 unit, peribadatan 430 unit, dan pendidikan 382 unit. Untuk meminimalisir kerugian dari adanya bencana terutama korban jiwa maka perlu menghadirkan masyarakat dalam mencegah atau menanggulanginya.

Langkah pertama yang perlu dilakukan adalah dengan meningkatkan pengetahuan dan kesadaran masyarakat di Indonesia tehadap pentingnya mitigasi bencana. Mitigasi bencana adalah upaya untuk mengurangi risiko yang ditimbulkan oleh bencana (jika terjadi bencana). Fokus dalam mitigasi bencana adalah untuk mengurangi dampak dari ancaman sehingga dampak negatif yang ditimbulkan akan berkurang (Nurjanah, dkk., 2013). Mitigasi bencana memiliki kaitan dengan tujuan SDGs (Sustainable Development Goals) ke 13 yaitu Penanganan Perubahan Iklim dengan mengambil aksi segera untuk memerangi perubahan iklim dan dampaknya. Indonesia perlu bercermin dari negara yang juga rawan bencana seperti Jepang, yang sudah dari dulu menyadari bahwa pengembangan strategi penanggulangan untuk bencana alam sangat penting bagi perlindungan dan pembangunan negara, serta pendidikan untuk bencana (bosai kyoiku) telah dipraktikkan dalam pendidikan formal dan informal sebagai bagian dari kesiapsiagaan bencana.

Pendidikan adalah proses untuk mengurangi bencana secara efektif karena pendidikan dapat menyelamatkan dan mempertahankan kehidupan, menawarkan perlindungan fisik dan psikososial, dan pada saat yang sama, memberi orang harapan untuk masa depan dan berfungsi sebagai saluran yang mempromosikan keselamatan dan kesejahteraan (Shaw et al., 2011). Hal ini sudah disadari oleh negara Jepang yang dibuktikan dengan dibuatnya buku panduan dengan judul Pengembangan Pendidikan Bencana 'Semangat untuk Hidup' pada tahun 1998. Ini adalah dokumen referensi pertama yang menargetkan pendidikan bencana, yang memperjelas posisi ide dalam keamanan sekolah dan menguraikan kegiatan belajar mengajar sesuai dengan setiap siklus bencana. Dokumen tersebut didistribusikan ke setiap sekolah di seluruh Jepang (Kitagawa, 2014).

Sumber daya manusia yang bermutu hanya dapat diwujudkan dengan pendidikan yang bermutu. Dengan pendidikan bermutu, pendidikan menghasilkan tenaga-tenaga muda potensial yang tangguh (Widodo, 2015). Di lain sisi, pengetahuan masyarakat di Indonesia tehadap kebencanaan khususnya mitigasi bencana masih kurang. Oleh karena itu, diperlukan pendidikan yang melibatkan masyarakat dalam upaya mitigasi bencana. Pendidikan kebencanaan khususnya mitigasi bencana sejak usia dini terutama pada sekolah dasar diperlukan untuk membentuk generasi muda yang tangguh bencana sehingga di masa depan akan terbentuk masyarakat Indonesia yang tangguh bencana. 
Untuk memudahkan generasi muda dalam menerima pendidikan kebencanaan, maka dibutuhkan media pembelajaran yang interaktif. Media pembelajaran adalah segala sesuatu yang menjadi sarana penyampaian informasi dari pengirim kepada penerima sehingga apa yang disampaikan dapat diterima dengan baik (Sari dan Ananda, 2018). Maka media pembelajaran yang tepat dalam penyampaian materi pendidikan kebencanaan sangat diperlukan guna mendukung tersampaikannya materi secara efektif dan efisien dalam mewujudkan generasi tangguh bencana di Indonesia.

Di lain sisi, Indonesia memiliki berbagai bentuk kearifan lokal yang mana keberadaannya semakin terancam oleh perkembangan zaman yang semakin maju. Salah satu bentuk kearifan lokal yang sangat mencolok ditinggalkan adalah permainan tradisional. Permainan tradisional Indonesia yang dominan menawarkan pemain untuk bermain di tanah lapang, biaya murah, dan berkelompok mulai tersingkirkan dengan keberadaan permainan gadget yang bersifat individualis dan membutuhkan kuota internet. Contoh dari permainan Indonesia dengan biaya murah tetapi memiliki keseruan di dalamnya yaitu permainan ular tangga. Padahal, permainan ini dapat membentuk 13 karakter dari 18 karakter yang terdapat pada ketentuan Kemendiknas, yaitu: jujur, toleransi, disiplin, kerja keras, kreatif, mandiri, demokratis, rasa ingin tahu, menghargai prestasi, bersahabat atau komunikatif, peduli sosial, peduli lingkungan, dan bertanggung jawab (Rahaju, 2015). Sehingga permainan ini layak untuk dilestarikan dengan dimanfaatkan sebagai media pembelajaran, karena selain biaya murah, masih cukup dikenal generasi muda, dan mudah digunakan, permainan ini juga memuat penanaman nilai karakter yang terbilang cukup banyak bagi sebuah permainan yang tujuan utamanya sebagai hiburan. Sehingga pendekatan yang digunakan melalui media pembelajaran ini adalah pendekatan bermain sambil belajar. Kelebihan pendekatan ini adalah melibatkan keaktifan siswa dalam pembelajaran dikarenakan pembelajaran melalui permainan dapat mengajak setiap siswa untuk mencoba hal-hal baru (Chabib, dkk., 2017). Pendekatan ini dirasa tepat untuk digunakan karena anak-anak memiliki rasa ingin tahu yang tinggi dan bermain adalah pekerjaan anak.

Media pembelajaran dengan menggabungkan antara permainan ular tangga dengan materi pendidikan kebencanaan merupakan sebuah inovasi yang tepat dan layak untuk dikembangkan di era disrupsi teknologi seperti sekarang ini. Inovasi ini dinamakan PERUT SINCAN (Permainan Ular Tangga Mitigasi Bencana) sebagai media pembelajaran pendidikan kebencanaan. Adapun rumusan masalahnya yaitu, 1) Bagaimana konsep penerapan PERUT SINCAN?; 2) Bagaimana implikasi PERUT SINCAN? Dengan tujuannya yaitu: 1) Menjelaskan konsep penerapan PERUT SINCAN; 2) Memaparkan implikasi PERUT SINCAN.

\section{METODE}

Jenis penulisan yang digunakan adalah deskriptif kualitatif, data yang diperoleh bukan berupa data statistik atau data angka, melainkan data bersifat kualitatif. Teknik pengumpulan data yang digunakan pada penulisan ini meliputi studi literatur (baik cetak maupun elektronik) serta observasi atau pengamatan. Prosedur pengumpulan data menggunakan teknik analisis dokumen jurnal, artikel, buku, dan sebagainya. Penulis menganalisis data dengan cara mengkaji jurnal, artikel, buku, dan sebagainya dari sumber terpercaya melalui internet. Selanjutnya data yang diperoleh dianalisa untuk mengembangkan konsep yang sesuai dalam mengatasi permasalahan.

Data dalam penulisan ini menggunakan data sekunder yang bersumber dari jurnal, artikel ilmiah, dan sebagainya. Sumber data sekunder diperoleh dari dokumentasi jurnal ilmiah, buku, dan literatur lain untuk menunjang pengembangan PERUT SINCAN sebagai media pembelajaran pendidikan kebencanaan. Teknik 
analisis data yang digunakan pada penelitian ini mengacu pada pendapat Miles dan Huberman yang menggunakan model analisis interaktif. Adapun tahapan yang dilakukan adalah reduksi data, penyajian data, dan penarikan kesimpulan.

\section{HASIL DAN PEMBAHASAN}

Permainan ular tangga merupakan salah satu permainan tradisional yang biasanya dimainkan oleh anak SD (Sekolah Dasar). Menurut Askalin (2013), permainan ular tangga adalah permainan yang dikenal di seluruh Nusantara. Permainan ini menggunakan tiga peralatan, yaitu dadu, bidak, dan papan ular tangga dengan jumlah pos sebanyak 100 yang dimainkan oleh dua orang atau lebih. Permainan ular tangga diawali dengan menentukan pemain yang akan bermain paling awal sampai terakhir, urutan pemain tersebut digunakan sampai permainan berakhir. Kemudian, pemain yang akan bermain mengocok dadu lalu dilemparkan, selanjutnya menggerakkan bidak untuk melangkah di papan ular tangga sesuai dengan jumlah titik-titik yang tertera pada dadu. Adapun papan ular tangga dilengkapi dengan gambar ular dan tangga yang memiliki makna. Apabila bidak berhenti pada gambar tangga berarti bidak akan bergerak naik, sedangkan apabila bidak berhenti di ekor ular maka bidak akan bergerak turun menuju pos kepala ular. Pemenang permainan ular tangga ini berdasarkan bidak pemain yang paling cepat sampai ke pos finish. Permainan ular tangga yang cukup mudah untuk dilakukan, membuat permainan tradisional ini disukai dan banyak dimainkan oleh anak-anak sehingga permainan ini sudah seharusnya tetap dilestarikan agar tidak hilang tergerus zaman.

Permainan ular tangga sebagai media pembelajaran merupakan salah satu cara melestarikan, memperkenalkan, dan mengoptimalkan daya tarik permainan ular tangga yang sebelumnya sudah disukai anak-anak untuk digunakan sebagai perantara penyampaian materi di dunia pendidikan. Penggunaan permainan ular tangga sebagai media pembelajaran sudah pernah diterapkan di beberapa penelitian yang bertujuan memudahkan siswa dalam menerima materi pembelajaran yang disampaikan oleh guru. Salah satu penelitian yang mengangkat permainan ular tangga sebagai media pembelajaran adalah penelitian yang berjudul Penerapan Permainan Ular Tangga dalam Pengajaran Kosakata. Penelitian ini menggunakan permainan ular tangga untuk mengajar kosakata dalam bahasa Inggris lalu mempraktikkannya dalam berbicara. Berdasarkan hasil dari pre-test dan post-test, penggunaan permainan ular tangga dapat meningkatkan kosakata siswa yang mana siswa merasa senang selama proses pembelajaran yang terbukti dengan tidak adanya masalah yang dihadapi siswa atau guru selama proses pembelajaran (Meipina, 2014). Penggunaan media pembelajaran tersebut tentunya sangat menguntungkan atau memberikan kemudahan bagi siswa dalam menerima materi dan guru dalam menyampaikan materi. 

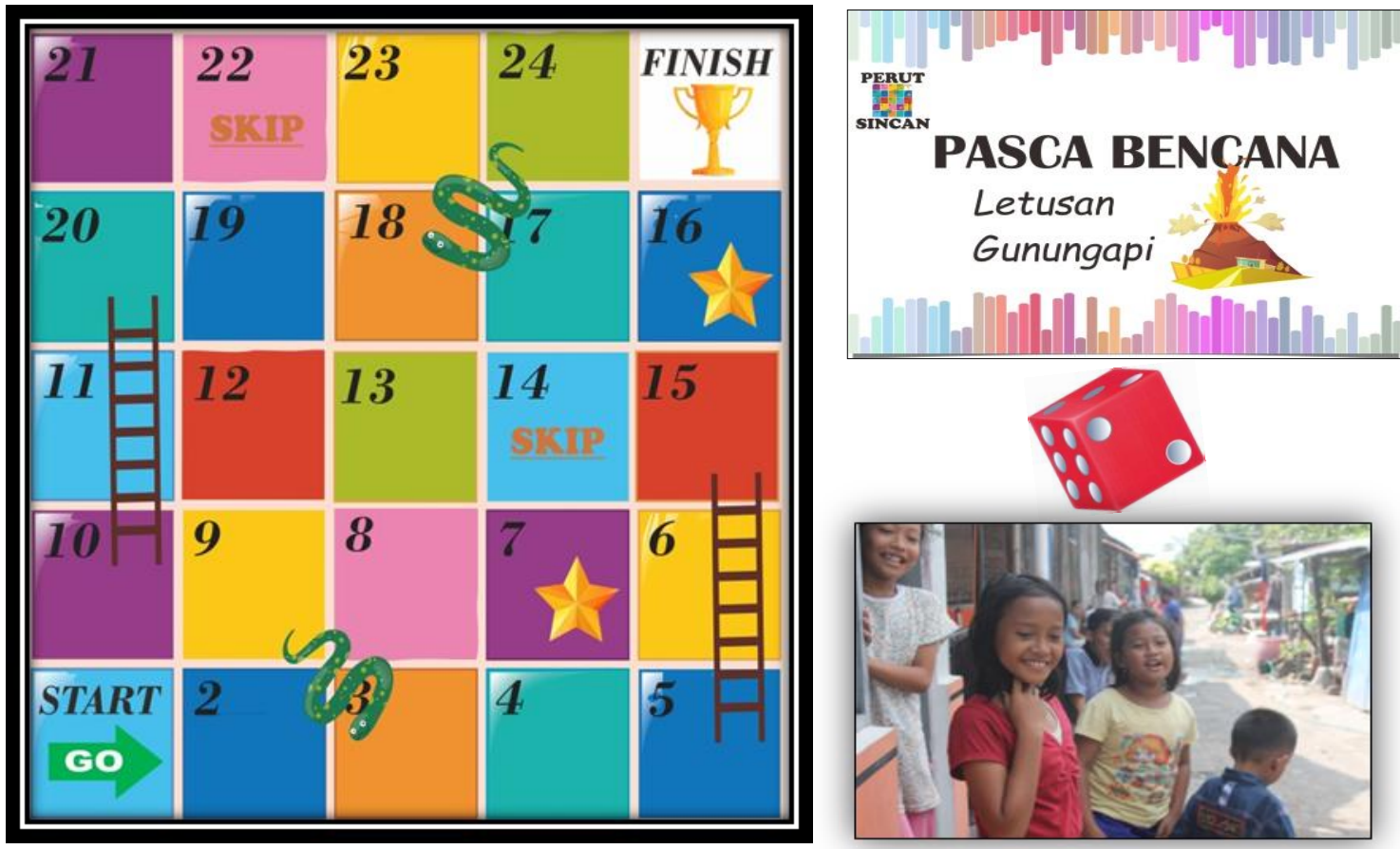

Gambar 1. Perlengkapan PERUT SINCAN

Media pembelajaran melalui permainan ular tangga dapat menjadi solusi dari permasalahan sulitnya menerima materi pembelajaran dari guru sekaligus melestarikan permainan tradisional. Hal tersebut dapat diwujudkan melalui PERUT SINCAN (Permainan Ular Tangga Mitigasi Bencana). PERUT SINCAN merupakan pemanfaatan permainan tradisional ular tangga sebagai media pembelajaran dalam penyampaian materi kebencanaan khususnya mitigasi bencana. Adapun alat dan bahan yang dibutuhkan dalam permainan ini yaitu sebagai berikut.

a. Papan ular tangga dengan jumlah pos sebanyak 25 yang mana dalam satu pos memiliki ukuran $0,5 \mathrm{~m} \times 0,5 \mathrm{~m}$ sehingga secara keseluruhan papan ular tangga ini berukuran $2,5 \mathrm{~m} \times 2,5 \mathrm{~m}$. Papan ular tangga ini dilengkapi dengan adanya tambahan gambar bintang dan kata SKIP. Bintang berarti apabila pemain salah menjawab pertanyaan, maka diberi kesempatan untuk melempar dadu atau melangkah. Jumlah kesempatan tersebut berdasarkan jumlah bintang yang telah dikumpulkan pemain atau satu kesempatan sama dengan satu bintang. Sedangkan, kata SKIP berarti pemain tidak bermain untuk sementara atau dilompati.

b. Dadu, dapat dibuat dengan menggunakan kardus bekas dan didesain semenarik mungkin.

c. Wasit, berjumlah satu orang yang dapat diperankan oleh orang tua atau guru.

d. Kartu bencana, berisi tantangan atau pertanyaan materi prabencana, saat terjadi bencana, pascabencana, menyebutkan contoh bencana di sekitar, dan pertanyaanpertanyaan lainnya terkait bencana.

e. Pemain, berupa anak-anak untuk berdiri langsung di papan ular tangga sebagai pengganti bidak.

Permainan ini didahului dengan menentukan pemain yang akan bermain paling awal sampai terakhir. Kemudian, wasit akan mengocok kartu bencana lalu pemain yang akan bermain diminta untuk memilih salah satu dari kartu bencana tersebut. Apabila pemain dapat menjawab pertanyaan atau melaksanakan tantangan, maka pemain diperbolehkan melempar dadu dan melangkah sesuai dengan jumlah titik-titik yang tertera pada dadu. Sedangkan, apabila pemain salah dalam menjawab dadu atau tidak mampu melaksanakan tantangan maka pemain tidak diperbolehkan untuk melempar dadu atau diam di tempat saja. Dengan demikian, dalam penerapan PERUT 
SINCAN memuat pelestarian permainan tradisional (adanya tambahan gambar bintang, kata SKIP, dan kartu bencana), pengenalan pendidikan kebencanaan (memuat materi kebencanaan), menumbuhkan kesadaran pentingnya pendidikan kebencanaan (anak berpartisipasi sebagai pemain), tampilan menarik agar anak tidak bosan (tambahan ikon menjadi daya tarik), dan aman digunakan karena dalam pengawasan guru atau orang tua yang berperan sebagai wasit.

Adapun Implementasi PERUT SINCAN (Permainan Ular Tangga Mitigasi Bencana) yaitu sebagai berikut.

a. Pengisi kegiatan sekolah, Kemendikbud menerbitkan buku bacaan berkualitas bagi masyarakat Indonesia yaitu buku dengan judul Bersahabat dengan Bencana Alam untuk kelas 4, 5, dan 6 sekolah dasar. Sehingga PERUT SINCAN dapat digunakan sebagai media pembelajaran pada saat istirahat atau pelajaran kosong dengan materi yang diambil dari buku ini. Selain itu, pada anak kelas 1 sekolah dasar pada tema 8 yaitu Peristiwa Alam terdapat materi Bencana Alam pada subtema 4. Dalam hal ini, PERUT SINCAN dapat digunakan sebagai media pembelajaran atau evaluasi materi yang telah disampaikan oleh guru.

b. Pengisi kegiatan di rumah, dapat digunakan sebagai permainan atau rekreasi sekaligus belajar materi kebencanaan.

c. Sebagai kegiatan ekstrakurikuler, dapat dilakukan pada kegiatan ekstrakurikuler seperti ekstrakurikuler pramuka atau PMR (Palang Merah Remaja).

Dalam implikasinya, PERUT SINCAN diharapkan mampu mewujudkan generasi tangguh bencana dengan anak-anak sebagai pondasi awalnya. Sebagaimana penjelasan BNPB (2012) bahwa anak-anak memiliki peran dalam melembagakan aktivitas pengurangan risiko bencana dan juga memiliki peran untuk menjadi tutor sebaya bagi teman-teman mereka yang lain. Sehingga apabila sebelum bencana terjadi, saat terjadi, dan setelah bencana, anak-anak memiliki pengetahuan untuk menjaga dirinya sendiri atau orang lain di sekitarnya. Dengan demikian, PERUT SINCAN mengubah materi kebencanaan yang selama ini hanya disampaikan berupa teori saja, kurang menarik, dan sulit dipahami dapat dijadikan sebagai materi yang menyenangkan untuk dipelajari atau dipraktikkan sambil bermain.

\section{SIMPULAN}

Lokasi Indonesia yang rawan terhadap bencana, menuntut pendidikan kebencanaan perlu ditanamkan sejak dini. Terlebih lagi pendidikan kebencanaan di Indonesia pada anak usia dini masih kurang padahal hal ini juga termuat dalam tujuan SDGs 2030. Di lain sisi, era disrupsi teknologi mengakibatkan permainan tradisional mulai ditinggalkan karena anak-anak lebih tertarik pada gadget, padahal permainan tradisional memuat banyak nilai karakter salah satunya adalah permainan ular tangga. Oleh karena itu, pendidikan kebencanaan khususnya materi mitigasi bencana yang dikolaborasikan dengan permainan tradisional ular tangga adalah langkah yang tepat sebagai upaya untuk mewujudkan generasi tangguh bencana. Dengan adanya PERUT SINCAN (Permainan Ular Tangga Mitigasi Bencana) diharapkan dapat menambah wawasan dan menumbuhkan kesadaran pentingnya mitigasi bencana bagi anak-anak yang mana dapat diterapkan pada diri sendiri maupun lingkungan sekitar. PERUT SINCAN diharapkan dapat diimplementasikan secara terus-menerus untuk membentuk anak sedini mungkin sebagai generasi tangguh bencana sehingga dapat mewujudkan masyarakat Indonesia tangguh bencana di masa depan. Pengembangan terhadap media pembelajaran ini harus selalu dilakukan agar dalam implementasinya berjalan secara efektif dan efisien guna mendukung terwujudnya generasi tangguh bencana. Adanya pembaharuan pada permainan ini sangat diperlukan untuk mengikuti minat anak yang dinamis sehingga dapat menjadi daya tarik bagi anak-anak untuk memainkannya. 
DAFTAR PUSTAKA

Askalin. (2013). 100 Permainan dan Perlombaan Rakyat. Yogyakarta: ANDI.

Badan Nasional Penanggulangan Bencana. (2012). Peraturan Kepala BNPB tentang Pedoman Penerapan Sekolah/Madrasah Aman dari Bencana (Peraturan Kepala BNPB Nomor 4 tahun 2012). Jakarta: Penulis.

Badan Nasional Penanggulangan Bencana. (2020, 30 Juni). Hingga Akhir Juni 2020, Jumlah Kejadian Bencana Alam Lebih Rendah dari 2019. BNPB Online. Diakses dari https://bnpb.go.id

Badan Pengkajian dan Penerapan Teknologi. (2018, April 26). Siap Siaga Bencana, Perlu Penguatan Aspek Teknologi Berbasis Real Time dan Deteksi Dini. BPPT Online. Diakses dari https://www.bppt.go.id

Cahbib, M., Ery T. D., dan Kuswandi D. 2017. Efektivitas Pengembangan Media Permainan Ular Tangga sebagai Sarana Belajar Tematik SD. Jurnal Pendidikan, 2 (7), 910-918.

Desfandi, M. (2014). Urgensi Kurikulum Pendidikan Kebencanaan Berbasis Kearifan Lokal di Indonesia. Sosio Didaktika, 1 (2), 191-198.

Kitagawa, K. (2014). Continuity and Change in Disaster Education in Japan. History of Education, 44 (3), 371-390.

Meipina. (2014). The Application of Snakes and Ladders Game in Teaching Vocabulary. The Second International Conference on Education and Language (2 ${ }^{\text {nd }}$ ICEL) 2014. 380-387.

Nurjanah, R., Sugiharto, Dede K., Siswanto BP, dan Adikoesomo. 2013. Manajemen Bencana. Bandung: Alfabeta.

Rahaju. (2015). Peran Permainan Ular Tangga dalam Pembentukan Karakter pada Pembelajaran Matematika Realistik. Prosiding Seminar Nasional Matematika dan Pendidikan Matematika UMS 2015. 266-279.

Sari, A. P. dan Ananda S. (2018). The Development of Internet-Based Learning Economic Learning Media Using Moodle Approach. International Journal of Active Learning, 3 (2), 100-109.

Shaw, R., dkk. (2011). Disaster Education: An Introduction. Community, Environment and Disaster Risk Management, 7(1), 1-22.

Widodo, H. (2015). Potret Pendidikan di Indonesia dan Kesiapannya dalam Menghadapi Masyarakat Ekonomi Asia (MEA). Cendekia, 13 (2), 293-307. 